\title{
AN ANALYSIS OF FACTORS AFFECTING TOURISM BRANDS IN RURAL SETTLEMENTS OF IRAN (CASE STUDY: BINALOUD COUNTY)
}

\author{
Aliakbar Anabestani \\ Associate prof., Geography \& Rural Planning, Ferdowsi University of Mashhad, Mashhad, Iran. \\ anabestani@um.ac.ir
}

\begin{abstract}
Today, for a variety of reasons, communities create brands. One of the most important reason for creating tourism brands is to make a location seem attractive for tourists and encourage them to spend more time in an area and raise the residents' standards of living. In this study, the factors affecting the formation of a rural tourism brand are examined from the perspective of experts and university professors. This study is an applied research conducted in a descriptive-analytical method. A major part of the data were collected through field studies, interviews, and filling out questionnaires by 30 experts active in the area together with 42 rural managers. The findings of the study based on the results of fuzzy hierarchical analysis showed that among the three factors, the economic factors with impact coefficient of $54.6 \%$ had the highest effect, and physical-environmental factors with the impact coefficient of $16.7 \%$ had the lowest impact on creating rural tourism brand. There was a little difference between the results acquired from the experts of the organizations and the academics about the impact of the above factors. With the aim of identifying villages suitable for creating tourism brand, we applied TOPSIS technique, and proposed Jagharq village as the most appropriate rural area for creating rural tourism brand. We also identified 10 other rural areas as capable of creating tourism brands. According to the findings, the following guidelines are recommended: to introduce and advertise certain products of the rural areas in urban areas, to pay special attention to entrepreneurship in rural areas, to provide tourism facilities in rural areas, to restore cultural elements, and to give special attention to restoration of past cultural elements, customs and traditions.
\end{abstract}

Keywords: Rural tourism, special products, entrepreneurship, Fuzzy Analysis Hierarchical Process (FAHP), Binalud County.

\section{INTRODUCTION}

\section{Statement of problem}

Today, tourism is one of the most important components of development and welfare. According to World Tourism Organization, Iran is the tenth country in terms of natural and artificial attractions. However, it is the one hundredth country in the world with regard to number of tourists that it has attracted in 1999. Compared to other countries which have higher revenue from tourism, one can perceive that tourism revenues of Iran has been significantly low, and tourism industry in Iran is quite underdeveloped. In addition to the lack of international interactions with other countries of the world, the obstacle to creating tourism brand in Iran include the lack of uniformed views about attracting tourists into country, not using religious tourism attractions or not publicizing tourism. According to expert views on tourism, the use of concepts attributed to tourism brand has been very ineffective in Iranian tourism industry. The core of Iranian tourism brand is essentially weak and the nature and status of Iranian tourism brand is not clearly defined. Besides, due to the lack of tourism brands and not having clarified the tourism core, there has not been adequate investment and development projects in tourism facilities and services (Hemati \& Zahrani, 2014). In fact, tourism brand makes way for competition between different sectors of service industry, while on a broader level, it is competing with other tourism destinations in attracting tourists and offering more services, attracting investors and more investment and creating more job opportunities (Johansson, 2008). Meanwhile, some countries try to attract more tourists than others countries, this can be achieved when countries develop their domestic tourism. Rural tourism is a kind of the domestic tourism, which can facilitate the development of tourism at the national level. Attention to the rural tourism, especially in Third World countries is seen necessary (Amani et al., 2011). Currently, one of the reasons for the lack of rural tourism development is the lack of united tourism brands and inappropriate planning, as the project managers are not careful enough 
about the brands, and without considering its consequences have created obstacles for rural sustainable development. (Novghani et al., 2008).

Binalud County is not an exception. Studies show that considering the capabilities and potentials in rural tourism industry of the above County, attraction of tourists and the development of tourism is not in satisfactory conditions. Various factors are effective in creating the gap between current status and ideal one, including inadequate marketing advertisement (Ranjbarian et al. 2012) or in other words, branding. This study aims to identify the rural areas having a high capacity and potential for creating brands and symbols and the role of symbols in improving the quality of life in villages of the study areas. Therefore, this study seeks to provide an appropriate response to the following question: What are the most important factors affecting the creation of tourism brands in villages of the study area? In addition we try to identify the villages suitable for developing tourism brand in the study area?

\section{Background of Research}

Given the importance of brands in tourism at rural and urban settlements, evaluation studies have gradually begun to investigate the brand recognition and creation in recent years. Therefore, in this part we review the results of some studies conducted in Iran and other countries about the role of brands in tourism development in urban and rural settlements. In general, we noted that no specific studies have been conducted about creating brands and symbols in rural areas.

Popescu (2009) in his study "the branding potential of Bucharest: strategy and success factors" showed that Bucharest is still able to develop and revitalize through a brand. Vanolo (2008) conducted a study titled "the image of the creative city: Some reflections on urban branding in Turin" in which he discusses the role of creativity and initiatives among urban investors in Turin, Italy. Qu et al (2011) in a study titled "A model of destination branding: Integrating the concepts of the branding and destination image", shows that overall image was affected by three types of brand relationships and it should be seen as an important mediator between the brand relations and future performance of tourists. There have also been some similar studies in Iran which are discussed in the following lines:

Ayubi Yazdi et al. (2011) in a study entitled "the importance of brands and branding in tourist destinations" hold the idea that branding of a tourism destination is not only about creating a logo or slogan, but it is about acquiring distinctive elements of the destination in the form of a brand and how these elements are related through the components of the brand. These components include: identity, essence, character, image, characteristics and culture. The management of these components to create a unique position for tourism brands in the minds of the consumers is called "brand positioning". Mollazadeh \& Eftekharnia (2011) in his study "Evaluation of the effects of urban branding in attracting tourists" came to conclusion that the use of the brands to attract tourists to the city has several advantages: First, by using their copyright, the brand would remain in that city; besides, the brand could change to a symbol of quality that is used to reassure the visitors. Moreover, long-term use would be a short way to remind the potential tourists of all the benefits. Qalamkar Mo'azam (2012) in an article titled "the Role of Iranian villages in rural tourism brand" came to the conclusion that rural tourism brand helps to select appropriate tourism projects and acts as a guide for the planners and can make way for low-income rural residents to benefit the tourism industry as a source of income. Barezani \& Zargham Borojeni (2013) in an article entitled "pathology of Iranian tourism brand" have concluded that the core of Iranian tourism brand (composed of the character, positioning and brand commitment) has serious weakness and the efforts to create brands in Iran have been very poor. Karami et al., in a study titled "brand position in development of tourism and attracting tourists" concluded that the factors affecting the creation of a brand are: the sources of information (their volume and type), demographic factors such as age, education, psychological motivations and characteristics of the tourist destination. Ayubi Yazdi et al (2009) in a study titled "position and challenges of brand in tourist destinations" came to conclusion that tourism branding is more complex and to create a single identity in a destination, one should take into account the organizational culture of the area and analyze a variety of factors to create the identity of the destination in a way that includes all the stakeholders. Sorayyaee et al., (2012) in a study titled "the effect of urban branding image on tourism behavior in of Ramsar County" concluded that the image of the destination has an intermediary role between the components of "the image and brand relations, motivations and behavioral objectives'. A different and powerful image should not be the only goal of branding practices to draw the attention of customers, but it would act as an intermediator which affect the customers' 
performance which is directly linked to the success of tourist destinations. Therefore, in a competitive tourism market, tourist destinations should create a strong and positive brand image.

\section{THEORETICAL FRAMEWORK \\ Rural Tourism}

Today, tourism is one of the important sources of income and at the same time it is one of the factors effective in cultural exchange between countries (Sojasi et al., 2011). Accordingly, researchers seek to investigate the role of tourism in socio-economic development of host communities in different levels of settlements. Tourism is of such an importance that it is believed to be a social phenomenon (Hultman \& Hall, 2011) and considering its multi-dimensional nature, it does play a significant role in empowering the host community and enhancing the socio-economic changes (Dwyer et al., 2009 \& Ateljevic, 2007). Rural tourism is one of the developing subsidiaries of tourism which has an increasing number of advocates. Rural tourism as a part of the tourism industry can play a significant role in empowering the local people and diversification of economic growth which can create new job opportunities in rural areas and other related sectors of the economy. From 1950s, tourism has become the focus of attention and from 1960s its economic dimensions have caught the attention of local communities. In the following decades, rural tourism was used as a tool for the development of rural communities, and in the meantime the experts have attempted to provide different models and approaches to increase the role of tourism in economic and social revitalization of rural areas (Jalalian et al., 2015). Any definition suggested for rural tourism, this activity provides relatively good background for rural development which can also provide good opportunities and facilities for rural employment and income-raising opportunities, and have a particularly important role in rehabilitation and modernization of rural areas (Mohammadi, 2011). In fact, rural tourism has developed as a form of tourism with the purpose of sustainable development of rural communities in rural areas and a tool for socio-economic development and as a modern business in rural areas (Ahmadian et al., 2015).

Economically, rural tourism could be studied in the framework of "supply-demand" and its development depends on three key factors:

1 - Attractions (natural and cultural beauties of rural areas);

2 -To provide the infrastructure and tourist services (roads, access, security, places of accommodation and catering, waste disposal and sewage systems);

3 - Cultural-commercial management (training, advertising, commercial facilities) (Zahedi, 2006).

\section{Concepts and meanings of brands}

In various studies conducted on brands, different definitions have been provided, some of which are briefly discussed in the following lines;

$>\quad$ Brand is a special intangible property that might be the main property of many businesses. As the brands have economic value, this category of assets (brands) have a significant effect on customer's choice, selection of staff, investors and government authorities. In the world of numerous choices, such an influence on commercial positioning and creating value for the shareholders is highly valuable and essential. Even nonprofit organizations also view brand as a key asset through which they can attract a variety of grants, donations and voluntary aids (Najafipour et al., 2012).

$>\quad$ Brand is the recognition of products or services of a seller or group of sellers and to differentiate those goods and services from their competitors' products (Aaker, 1991).

Destination brand is a name, symbol, logo, trademark or any other graphics which defines the destination and distinguishes it. Besides, it promises the experience of a memorable journey to the tourists (which is exclusively the characteristics of the destination) (Ritchie \& Ritchie, 1998).

Travelling brand is sometimes called "tourism brand". Most cities and places are more willing to have a tourism brand rather than an umbrella brand, as brands have a stronger voice and act in a more organized manner in interaction with geographical features (Baker, 2012). 
Tourism destination branding creates an image of the destination in the minds of the tourists and is the main factor in a tourist's considerations and criteria for decision-making (Kaplanidou \& Vogt, 2003).

$>\quad$ Bose Alen and Hamilton have a different definition for tourism: trademark is a shortcut for linking to the market through the data. Leslie d Chernatony, professor of Marketing School of Free Business of the United Kingdom believes, brand is the active participation in any relationship, or between customers and brand, or between employers and employees, employees and customers or employees and other stakeholder (Dastjerdi Yousefi, 2006).

Rooney believes that brand is an expression, sign, symbol or a combination of them which is intended to identify the products and services of a seller or a group of them from products and services of other sellers.

American Marketing Association (2007) defines branding as a name, term, design, symbol, or any other feature that identifies one seller's good or service as distinct from those of other sellers (Johansson, 2007).

\section{Brand and tourism development}

Generally, tourists, especially potential tourists do not have enough time to do research about all their destinations. On the other hand, they will visit a city or a place only if they are assured about the logical benefits they will gain from the trip they are going to make. Therefore, the consumers (tourists) use the information a brand provides as a tool to select a product that meets their needs. Therefore, good and innovative design of brands and their messages and the advertisement of a brand designed for a town, will quickly and easily benefit the tourists. Creating a successful brand that can advertise a place for potential tourists in short phrases or sentences is highly efficient in attracting them, and this would make way for the efficient use of resources. To design unsuccessful and irrelevant brands do not attract tourists and would make them pessimistic about the features and benefits of the location and this means a waste of time and money.

An important point in the evaluation of a successful brand is the emotional appeal of the brand message, in other words, to what extent has the brand message been successful in stimulating the emotions of the tourists and encouraging them. The second point is the beauty and attractions of the village and its relevance to the brand created. After creating a brand, to conjoin the interests of the location to the brand, the brand message should be advertised on all promotional items such as brochures, local monthly and weekly magazines, local newspapers, local or provincial television networks, banners and billboards, on the cover of souvenirs and so on. Besides, in order to achieve maximum results and attract more tourists, experts in tourism industry especially marketers should work to build brand loyalty. If a successful tourism brand is created which will also create a pleasant tourist experience, continuous use of the brand would remind the tourists of their previous pleasant and enjoyable experience which tells him or her that there is still a good experience and nothing has changed that inherently attract them back. Therefore, in brief one can say that the loyalty to a brand is based on the relationship between the location (cities-rural areas) and visitors and ensures that when the visitor is planning to visit an area again, the memories associated with those places are first things that comes to their minds (Mollazadeh et al., 2011).

Clark has mentioned six advantages for the role of brand in attracting the tourists:

As tourism product are highly complex, branding helps to limit the domain of the selection (confusion will be reduced).

$>\quad$ Branding will reduce the problems caused by intangibility of tourism products.

$>\quad$ Branding preserves the cohesion and stability in the markets and different time periods.

$>\quad$ Branding reduces risks factor connected with decision-makings about holidays.

$>$ Branding facilitates the exact segmentation process of the market. 
Branding helps the efforts made by the service provider become more centralized and coordinated. This way, the individuals work to achieve the same and coordinated results (Baker \& Cameron, 2008).

In addition, the following points are worth attention:

Branding strategies of different places are very important for strengthening the competition power of tourism destinations.

$>\quad$ Branding is a communication tool which creates and maintains competitive advantages.

$>\quad$ Brand is the most important marketing tool to build differentiation, and stimulate consumer emotions and encourage him to buy. Brands have social and emotional values for the consumers. Brand has a personality and speaks to the consumer (Kiani, 2008).

Tourism is a service industry. For this reason, tourism products are provided in the framework of creating different experiences. Since it is difficult to sale an experience, branding can collect an experience as a single element that is easier to market (Blain, 2001).

\section{Factors affecting creation of a tourism brand}

The review of literature shows that factors affecting creation of a tourism brand for a tourism destination, for those who have not visited it, or have no previous experience of the destination include: tourism incentives, demographic properties and various information sources. The concept of brand is primarily an observational structure that includes mental outcomes of a person about knowledge, beliefs, feelings and general understanding of an object or a destination. Researchers in various fields believe that brand structure has two dimensions or evaluation:

A) Perceptual-cognitive evaluations,

b) Emotional evaluations;

Perceptual-cognitive evaluations refer to the knowledge and beliefs of an individual about perceptual features of a destination, and the emotional evaluations are associated with the sensation or feelings towards a destination. It is generally accepted that emotional reactions of an individual depends on his perceptualcognitive evaluations and his emotional reactions are a representation of perceptual reactions of the individuals. But a comprehensive brand of a place is created as a result of the total perceptual-cognitive and emotional evaluations of a place. The following diagram shows a general framework for creation of a tourism destination brand. Many researchers in different scientific fields agree that two important factors are involved in creation of a brand:

\section{A) Motivational factors}

Motivational factors have their origin in external incentives, physical factors and also past experience of an individual.

\section{B) Individual factors}

Individual factors are the social and psychological characteristics of an individual. 


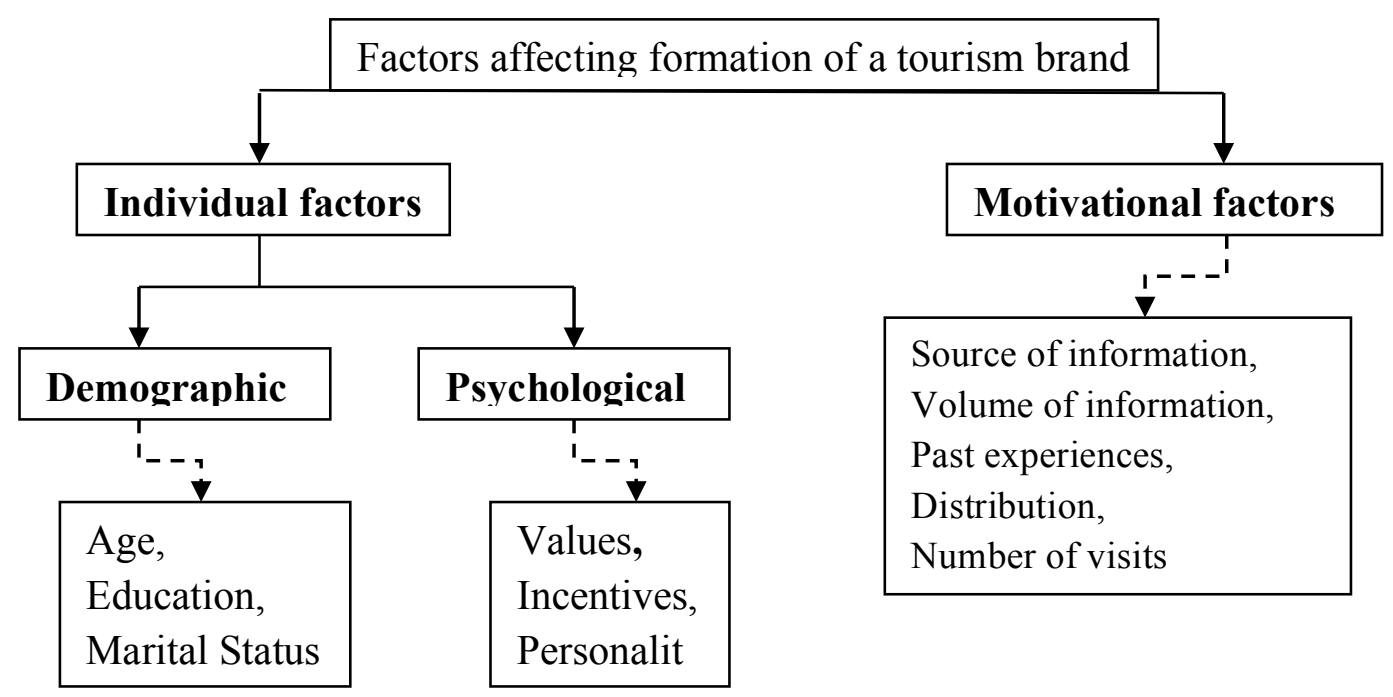

Figure 1 - A general framework for formation of a tourism brand from a tourism destination

(Baloglu \& McCleary, 1999)

The literature revealed that a series of factors are effective in formation of a brand. These factors include: a) information sources and raising awareness about the destination, b) individual factors. Both information driven factors and individual factors are effective in formation of a brand. In the model of Bearly and Martin (2004) and in the model proposed by Baloglu and McCleary (1999 a) there is a distinction between the stimuli (information sources, past experiences, distribution of visits) and individual factors (demographic and psychological factors). Therefore, considering the general factors that are related to the formation of a brand, it should be noted that the development of tourism brand in rural areas are in compliance with the above general principles, and a series of economic, social and environmental factors depicted in the following chart.

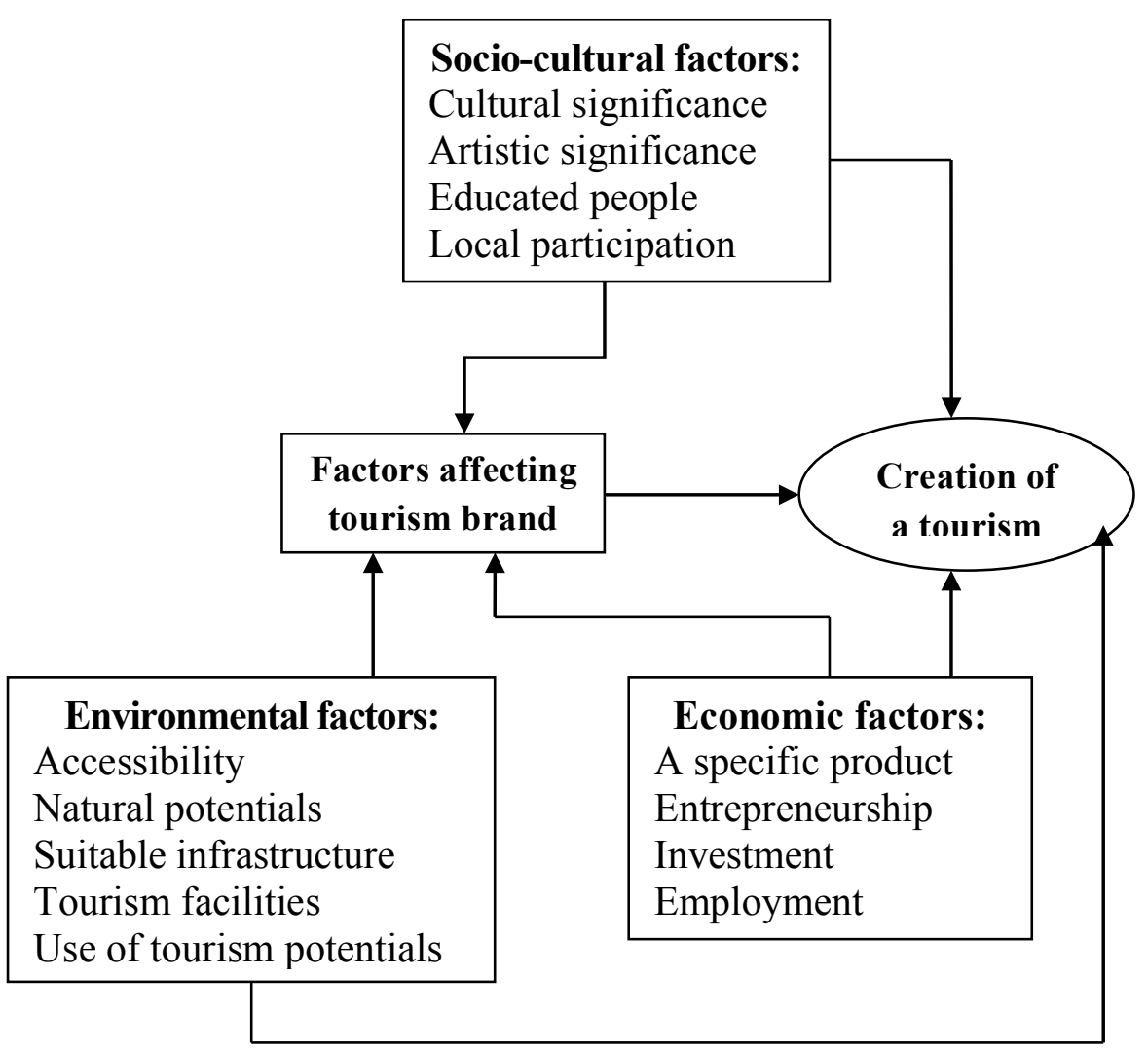


Figure-2 factors affecting the formation of a tourism brand

(Source: Research findings, 2015)

\section{GEOGRAPHIC FEATURES OF THE STUDY AREA}

Geographic location represents many rural properties, including population size, types of activities, accessible resources and potentials for growth and development. Accordingly, a plain compared to a mountainous location is significantly different from various aspects (Saeedy, 2000). The study area included Binalud County (Torghabeh and Shandiz), in southwest of Mashhad. Binalud County is situated in northeast of Islamic republic of Iran, it is bordering Mashhad County in North and East, it is bordering Chenaran County in the West and it is bordering Nishapur in northwest. Binalud County is located between $95^{\circ}$ and 59 ${ }^{\circ}$ East longitude, and 35 minutes, and 41 seconds Eastern longitude, and 36 degrees and 6 minutes and 5 seconds to 36 degrees, 31 minutes 24 seconds Northern latitude, with an area of about 1161 square kilometers, equivalent to one percent of the total area of Razavi Khorasan Province. The distance between Torghabeh and Mashhad County is 4 kilometers, and Torghabeh County is located at an altitude of 1351 meters above sea level. Up to 2007, this area was one of the sub-divisions of Mashhad County. But in January 2007, it was promoted to a county by a decree of Council of Ministers. According to the latest decree of Council of Ministers, Binalud County has two districts (bakhsh): Torqabeh District and Shandiz District. It has four rural districts (Dehestan) including Abar deh, Shandiz, Jagharq and Torghabeh, and it has two towns: Torghabeh and Shandiz (Governor of Khorasan-e-Razavi, 2015).

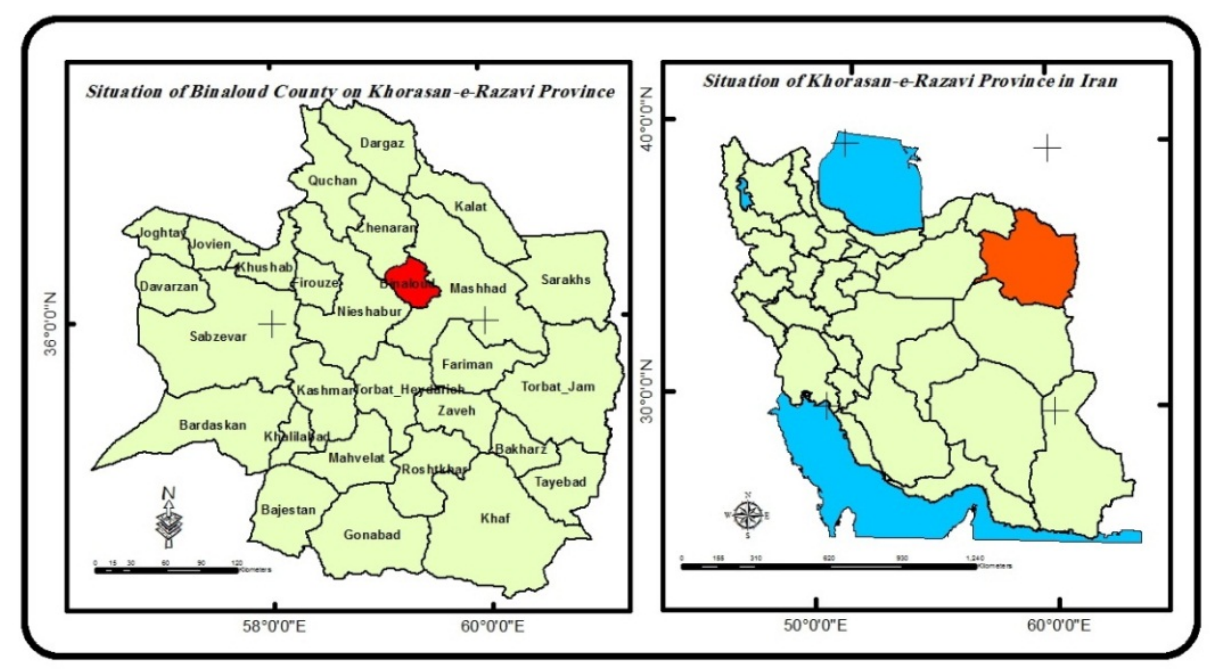

Figure 3 - Geographical location of the study area

(Source: Research findings, 2015)

\section{RESEARCH METHODOLOGY}

To use a methodology, we mean to utilize the principles and frameworks that will guide the research. Clearly, the research methodology will be different based on the type, purpose and subject of the study. This study is an applied quantitative study benefiting field works for data collection and is based on descriptivesurvey analysis. The data were collected through documentary research and field works. In documentary method, the researcher takes notes from books and documents and could be used in all scientific researches. We mainly tried to find the information and the results of previous relevant studies, so that we may find a general framework for topics discussed in this research through reviewing the literature of the study.

To investigate the factors affecting the formation of a rural tourism brand, we used Fuzzy Analytic Hierarchy Process (FAHP) and then ranked the villages of the study area through Technique for Order Preference by Similarity to Ideal Solution (TOPSIS). 
Following the bugs found in Analytic Hierarchy Process (AHP), including the existence of unbalanced scales in judgments, uncertainties, imprecise paired comparisons and not fully reflecting the style of human thought, Fuzzy Analytic Hierarchy Process (FAHP) for the first time was proposed in 1983 by two fellow Dutch Van laarhoven and Pedrycz. This method is based on replacing the triangular fuzzy numbers in the matrix of paired comparison based on logarithmic least square (Pourtaheri, 2010; Ataee, 2010; Habibi et al., 2014).

The following steps were taken in FAHP method:

1- $\quad$ To draw a AHP chart;

2- $\quad$ To make paired comparison matrix using fuzzy numbers;

3- $\quad$ To calculate normalized Fuzzy weight of each element ( $\mathrm{Si}$ ) for each line of paired comparison matrix;

4- To calculate the value of Si compared to each other;

5- $\quad$ To measure the weight of criteria and options in paired comparison matrices; and

6- To calculate the final weight vector (Ataee, 2010).

TOPSIS technique is a good way to find the best option, it is based on the concept that the chosen alternative should have the shortest geometric distance from the positive ideal solution and the longest geometric distance from the negative ideal solution. This technique consists of six steps including: to calculate the normalized decision matrix, to normalize the decision, to calculate the weighted normalized decision matrix, to identify positive and negative ideas, to calculate the distance from positive and negative ideals, to calculate the similarity to the worst or best condition (Habibi et al, 2014).

FAHP Solver 2014 was used for paired comparisons, and production of hierarchical processes and calculation of the weights in the hierarchical fuzzy process. To assign weight to criteria and sub-criteria, we utilized paired fuzzy comparisons which was conducted by two groups of experts of the organization (14 people) and the departments and faculties (16 people), and TOPSIS technique was used for rating the villages based on 14 indexes. For this purpose, two questionnaires were designed and filled out. One for paired comparisons which were filled out by 30 experts, and the other one was village questionnaires which were filled out by 42 rural managers of the villages of the study area. In these questionnaire, fourteen factors affecting the creation of a tourism brand in the villages of the study area were included and the villages were ranked using TOPSIS Solver 2014.

\section{RESULTS}

\section{Factors affecting the formation of a rural tourism brand}

Given the exploratory studies, three factors are involved in forming the rural tourism brand in economic, social, and physical-environmental fields.

B) Economic factors - Among the economic factors affecting the formation of a rural tourism brand, some indexes were identifies such as: the availability of specific products in a village, to have entrepreneurs and rural elites, capital investment, diversification of the economic activities, and the potentials of the region for capital investment. Among the respondents, three indexes including products, entrepreneurship and capital investment by coefficients of 26, 25 and 24 per cent ranked first to third. With regard to effects of economic factors, there was no difference between the views of experts from institutions, departments and university professors. However, with regard to 'availability of a specific product' experts of the institutions and departments assigned a weight of 29.2 percent to it; however, the professors assigned a weight of 24.8 percent. From the perspective of both groups and in general, the potential for tourism development was ranked last.

Table 1. Impact of economic factors on formation of a rural tourism brand

\begin{tabular}{|l|l|l|l|l|l|l|l|l|}
\hline Description & $\begin{array}{l}\text { Produc } \\
\mathrm{t}\end{array}$ & $\begin{array}{l}\text { Entrepreneurshi } \\
\mathrm{p}\end{array}$ & $\begin{array}{l}\text { Capita } \\
\mathrm{l}\end{array}$ & $\begin{array}{l}\text { Job- } \\
\text { creatio }\end{array}$ & $\begin{array}{l}\text { Touris } \\
\mathrm{m}\end{array}$ & $\begin{array}{l}\text { total } \\
\text { weigh }\end{array}$ & $\begin{array}{l}\text { Professor } \\
\mathrm{s}\end{array}$ & $\begin{array}{l}\text { Expert } \\
\mathrm{s}\end{array}$ \\
\hline
\end{tabular}




\begin{tabular}{|l|l|l|l|l|l|l|l|l|}
\hline & & & & $\mathrm{n}$ & & $\mathrm{t}$ & & \\
\hline Product & $(1,1,1)$ & $(2,4,6)$ & $(1,3,5)$ & $(5,7,9)$ & $(4,6,8)$ & 0.26 & 0.248 & 0.292 \\
\hline $\begin{array}{l}\text { Entrepreneurshi } \\
\mathrm{p}\end{array}$ & & $(1,1,1)$ & $(3,5,7)$ & $(6,8,10)$ & $(3,5,7)$ & 0.25 & 0.247 & 0.256 \\
\hline Capital & & & $(1,1,1)$ & $(7,9,11)$ & $(6,8,10)$ & 0.24 & 0.244 & 0.250 \\
\hline Job-creation & & & & $(1,1,1)$ & $(5,7,9)$ & 0.15 & 0.161 & 0.102 \\
\hline Tourism & & & & & $(1,1,1)$ & 0.10 & 0.10 & 0.10 \\
\hline
\end{tabular}

Source: Research findings, 2015.

B) social factors - Among the social factors effective in the formation of a rural tourism brand, some indexes were identified including: the cultural significance (antiquity, unique and rich rural culture and traditions in rural areas), the artistic significance (special crafts having artistic value), presence of educated people (trained and educated indigenous people in the village) and local participation (cooperation and participation of rural people in activities related to tourism). Among all respondents, two indexes of artistic and cultural significance with the impact coefficients of $38.2 \%$ and $25.8 \%$ respectively ranked first and second. With regard to ranking of social factors, there was no differences between the experts of institutions and university professors, but with respect to impact coefficients of cultural significance in the villages, experts of the institutions assigned a weight of 42.8 , while the university professors have assigned a weight of 35.6 per cent. From the perspective of both groups and in general the spirit of partnership among the local villagers was ranked last.

Table 2. Impact of social factors on formation of a rural tourism brand

\begin{tabular}{|l|l|l|l|l|l|l|l|}
\hline Description & Cultural & Art & Education & Partnership & $\begin{array}{l}\text { Total } \\
\text { weight }\end{array}$ & Professors & Experts \\
\hline Cultural & $(1,1,1)$ & $(6,8,10)$ & $(2,4,6)$ & $(2,4,6)$ & 0.382 & 0.356 & 0.428 \\
\hline Art & & $(1,1,1)$ & $(1,3,5)$ & $(1,3,5)$ & 0.258 & 0.269 & 0.229 \\
\hline Education & & & $(1,1,1)$ & $(3,5,7)$ & 0.235 & 0.250 & 0.218 \\
\hline Partnership & & & & $(1,1,1)$ & 0.125 & 0.125 & 0.125 \\
\hline
\end{tabular}

Source: Research findings, 2015.

C ) physical-environment factors - Among the physical-environmental factors effective in formation of a rural tourism brand, some indexes were identified such as: accessibility (proximity and short distance to Mashhad metropolitan and towns of Torghabeh and Shandiz), natural potentials (beautiful and unique natural scene in rural areas, sufficient water resources), suitable infrastructure (having basic infrastructure such as transportation, roads, electricity, gas and fresh water), tourism facilities ( tourism facilities in rural areas such as signs, fountains and tourist resorts,...) and the use of tourism potentials (potential for development of various kinds of tourism, including agricultural tourism, sports tourism, second home tourism, etc.). Among all the respondents, the indexes of availability and natural potentials with the impact coefficients of 28 and $26.8 \%$ ranked first and second. With respect to the ranking of the physical-environmental factors, no significant difference was found between experts of the institutions and professors. However, with respect to impact coefficient of access to the countryside, experts of institutions assigned a weight of 31.9 percent to it, while the professors assigned a weight of $26.5 \%$. From the perspective of both groups and in general, the use of tourism potentials in rural areas was ranked last.

Table 3. Impact of physical-environmental factors on formation of a rural tourism brand

\begin{tabular}{|c|c|c|c|c|c|c|c|c|}
\hline Description & Access & Natural & Infrastructure & Equipment & Property & $\begin{array}{c}\text { Total } \\
\text { weight }\end{array}$ & Professors & Experts \\
\hline Access & $(1,1,1)$ & $(4,6,8)$ & $(2,4,6)$ & $(4,6,8)$ & $(6,8,10)$ & 0.280 & 0.265 & 0.319 \\
\hline $\begin{array}{c}\text { Natural } \\
\text { beauties }\end{array}$ & & $(1,1,1)$ & $(6,8,10)$ & $(4,6,8)$ & $(6,8,10)$ & 0.268 & 0.252 & 0.295 \\
\hline infrastructure & & & $(1,1,1)$ & $(7,9,11)$ & $(4,6,8)$ & 0.214 & 0.228 & 0.186 \\
\hline Equipment & & & & $(1,1,1)$ & $(7,9,11)$ & 0.138 & 0.155 & 0.10 \\
\hline Property & & & & & $(1,1,1)$ & 0.10 & 0.10 & 0.10 \\
\hline
\end{tabular}


Source: Research findings, 2015.

Finally, of economic, social and physical-environment factors, according to the respondents, the economic factors with the impact coefficient of 54.6 percent was ranked first, social factors with impact coefficient of $28.8 \%$ was ranked the second, and physical-environment factors with a impact coefficient of $16.7 \%$ was ranked last. With regard to ranking of physical-environmental factors, no significant differences was found between expert of the institutions and university professors, but with regard to impact coefficient of economic factors in the villages, the experts of institutions assigned a weight of 50 per cent, while the professors assigned a weight of $57.2 \%$. This is also true about the social factors; however, its trend is contrary to economic factors.

Table 4. Impact of factors affecting the formation of a rural tourism brand

\begin{tabular}{|l|l|l|l|l|l|l|}
\hline Description & Economic & Social & $\begin{array}{l}\text { Physical- } \\
\text { environmental }\end{array}$ & $\begin{array}{l}\text { Total } \\
\text { weight }\end{array}$ & Professors & Experts \\
\hline Economic & $(1,1,1)$ & $(7,9,11)$ & $(2,4,6)$ & 0.546 & 0.572 & 0.500 \\
\hline Social & & $(1,1,1)$ & $(3,5,7)$ & 0.288 & 0.261 & 0.333 \\
\hline $\begin{array}{l}\text { Physical- } \\
\text { environmental }\end{array}$ & & & $(1,1,1)$ & 0.167 & 0.167 & 0.167 \\
\hline
\end{tabular}

Source: Research findings, 2015.

Results of ranking 14 indexes, using Fuzzy Analytical Hierarchy Process (FAHP) showed that three indexes of 'availability of specific products in the villages', ' presence of entrepreneurs in the villages' and 'capital investment in rural areas', with the impact coefficients of 14.2, 13.6 and $13.4 \%$ respectively ranked first to third. With regard to rankings based on 14 indexes, there was a significant difference between the views of experts from departments and organization and university professors, to the extent that university professors believed that three indexes of 'availability of specific products in the villages', 'presence of entrepreneurs in the villages' and 'capital investment in rural areas', with the impact coefficients of 14.2, 41.1 and $14 \%$ respectively ranked first to third. However, the experts from departments and organization believed that 'availability of specific product in the countryside', 'cultural significance' and presence of entrepreneurs in the villages' with the impact coefficients of 14.6, 14.3 and $12.8 \%$ respectively ranked first to third. The availability of tourism facilities and the 'use of tourism potentials' in rural areas with the impact coefficients of 2.3 and 1.7 percent, were ranked last and penultimate by experts and university professors.

Table 5 - Indexes effective in the formation of rural tourism brand

\begin{tabular}{|l|l|l|l|l|l|l|l|}
\hline \multirow{2}{*}{ Options } & Indicators & \multicolumn{2}{l|}{ Total } & \multicolumn{2}{l|}{ Professors } & \multicolumn{2}{l|}{ Experts } \\
\cline { 2 - 9 } & Weight & Rank & Weight & Rank & Weight & Rank \\
\hline Special products & $\begin{array}{l}\text { unique crops, fruits and } \\
\text { dairying }\end{array}$ & 0.142 & 1 & 0.142 & 1 & 0.146 & 1 \\
\hline Entrepreneurship & $\begin{array}{l}\text { To have entrepreneurs } \\
\text { and rural elites }\end{array}$ & 0.136 & 2 & 0.141 & 2 & 0.128 & 3 \\
\hline $\begin{array}{l}\text { Capital } \\
\text { Investment }\end{array}$ & $\begin{array}{l}\text { To have capital } \\
\text { investors both resident } \\
\text { and non-resident in the } \\
\text { villages }\end{array}$ & 0.134 & 3 & 0.140 & 3 & 0.125 & 4 \\
\hline $\begin{array}{l}\text { Employment } \\
\text { type of } \\
\text { economic } \\
\text { activities) }\end{array}$ & $\begin{array}{l}\text { tourism related service } \\
\text { jobs for tourism } \\
\text { development in the } \\
\text { village }\end{array}$ & 0.079 & 5 & 0.092 & 5 & 0.051 & 8 \\
\hline $\begin{array}{l}\text { Tourism } \\
\text { development }\end{array}$ & $\begin{array}{l}\text { High potentials of the } \\
\text { area for investment and } \\
\text { tourism planning }\end{array}$ & 0.055 & 8 & 0.057 & 8 & 0.050 & 9 \\
\hline $\begin{array}{l}\text { Cultural } \\
\text { significance }\end{array}$ & $\begin{array}{l}\text { antiquity, unique and rich } \\
\text { rural culture and traditions }\end{array}$ & 0.110 & 4 & 0.093 & 4 & 0.143 & 2 \\
\hline
\end{tabular}




\begin{tabular}{|c|c|c|c|c|c|c|c|}
\hline & in rural areas & & & & & & \\
\hline $\begin{array}{l}\text { Artistic } \\
\text { significance }\end{array}$ & $\begin{array}{l}\text { special crafts having } \\
\text { artistic value }\end{array}$ & 0.074 & 6 & 0.070 & 6 & 0.076 & 5 \\
\hline educated people & $\begin{array}{l}\text { trained and educated } \\
\text { indigenous people in the } \\
\text { village }\end{array}$ & 0.068 & 7 & 0.065 & 7 & 0.073 & 6 \\
\hline $\begin{array}{l}\text { Local } \\
\text { participation }\end{array}$ & $\begin{array}{l}\text { cooperation } \\
\text { participation of rural } \\
\text { people in activities } \\
\text { related to tourism }\end{array}$ & 0.036 & 11 & 0.033 & 12 & 0.042 & 11 \\
\hline Accessibility & $\begin{array}{l}\text { proximity and short } \\
\text { distance to Mashhad } \\
\text { metropolitan and towns of } \\
\text { Torghabeh and Shandiz }\end{array}$ & 0.047 & 9 & 0.044 & 9 & 0.053 & 7 \\
\hline $\begin{array}{l}\text { Natural } \\
\text { potentials }\end{array}$ & $\begin{array}{l}\text { beautiful and unique } \\
\text { natural scene in rural } \\
\text { areas, sufficient water } \\
\text { resources }\end{array}$ & 0.045 & 10 & 0.042 & 10 & 0.049 & 10 \\
\hline $\begin{array}{l}\text { Suitable } \\
\text { infrastructure }\end{array}$ & $\begin{array}{l}\text { having } \\
\text { infrastructure such as } \\
\text { transportation, roads, } \\
\text { electricity, gas and fresh } \\
\text { water }\end{array}$ & 0.036 & 11 & 0.038 & 11 & 0.031 & 12 \\
\hline $\begin{array}{l}\text { Tourism } \\
\text { facilities }\end{array}$ & $\begin{array}{l}\text { Tourism facilities in } \\
\text { rural areas such as } \\
\text { signs, fountains and } \\
\text { tourist resorts... }\end{array}$ & 0.023 & 12 & 0.026 & 13 & 0.017 & 13 \\
\hline $\begin{array}{l}\text { The use of } \\
\text { tourism } \\
\text { potentials }\end{array}$ & $\begin{array}{l}\text { potential } \\
\text { development of various } \\
\text { kinds of tourism, } \\
\text { including agricultural } \\
\text { tourism, sports tourism, } \\
\text { second home tourism, } \\
\text { etc. }\end{array}$ & 0.017 & 13 & 0.017 & 14 & 0.017 & 13 \\
\hline Sum & - & 1 & - & 1 & - & 1 & - \\
\hline
\end{tabular}

Source: Research findings, 2015.

\section{To identify villages suitable for the formation of a tourism brand in the study area}

To identify villages suitable for rural tourism in the study area, with regard to the 14 indexes and its indicators in the villages, a $14 \times 42$ matrix was created and calculated using TOPSIS technique of similarity to the ideal. The results after identifying the positive and negative ideal and measuring the distance to positive ideals in TOPSIS method showed that 11 village have near factor of higher than $50 \%$ to positive ideal, and the villages of Jagharq, Abrdeh Olia and Kang respectively with impact coefficients of 80.0, 58.1 and $57.4 \%$ are the most suitable villages for creating a tourism brand in the study area. On the other hand, 31 villages had near factor of less than $50 \%$ to the positive ideal, and among them, the villages of Sirzar, Hassan Abad and house manufacturing factory of Mashhad respectively with the impact coefficients of 11.62, 11.67 and 14.3 had a longer distance from the positive ideal; in other words, they were the least suitable villages for creating a rural tourism brand.

Table 5 - identification of villages suitable for rural tourism brand in the region

\begin{tabular}{|l|l|l|l|l|l|}
\hline $\begin{array}{l}\text { The name of } \\
\text { the village }\end{array}$ & Rank & Near factor & $\begin{array}{l}\text { The name of the } \\
\text { village }\end{array}$ & Rank & $\begin{array}{l}\text { Near } \\
\text { factor }\end{array}$ \\
\hline
\end{tabular}




\begin{tabular}{|l|l|l|l|l|l|}
\hline & 1 & 0.800136 & Mayan Olia & 22 & 0.386504 \\
\hline Olia Abrdeh & 2 & 0.581457 & Chelated Ahan & 23 & 0.380292 \\
\hline Kong & 3 & 0.574246 & Farah-Abad & 24 & 0.359236 \\
\hline Dehbar & 4 & 0.559662 & Tajar & 25 & 0.358239 \\
\hline Gorakhak & 5 & 0.537367 & Islam-rud & 26 & 0.356905 \\
\hline Abrdeh Sofla & 6 & 0.529927 & Suran & 27 & 0.349223 \\
\hline Zoshk Olia & 7 & 0.518688 & Chah Khaseh & 28 & 0.33795 \\
\hline Hesar & 8 & 0.518332 & Sar-Borj & 29 & 0.337857 \\
\hline Sarasiab & 9 & 0.512032 & Hesar Sorkh & 30 & 0.327053 \\
\hline Azghad & 10 & 0.508926 & Chelateh Abdul & 31 & 0.311574 \\
\hline $\begin{array}{l}\text { Zoshk } \\
\text { Village }\end{array}$ & 11 & 0.508193 & Hosein Abad Jaldak & 32 & 0.280889 \\
\hline Virani & 12 & 0.484197 & Fiyani & 33 & 0.251548 \\
\hline Zoshk Sofla & 13 & 0.475679 & Chahshak & 34 & 0.24831 \\
\hline Safiabad & 14 & 0.466233 & Toos Industrial Park & 35 & 0.234512 \\
\hline Ardameh & 15 & 0.465901 & Dehno & 36 & 0.201881 \\
\hline Nogondar & 16 & 0.442031 & Moj & 37 & 0.178637 \\
\hline Nowchah & 17 & 0.427708 & Sham-Ali & 38 & 0.160807 \\
\hline $\begin{array}{l}\text { Mayan } \\
\text { Soflah }\end{array}$ & 18 & 0.411596 & Hiteh Zoshk & 39 & 0.160758 \\
\hline Mogan & 19 & 0.394673 & $\begin{array}{l}\text { House- } \\
\text { manufacturing } \\
\text { factory of Mashhad }\end{array}$ & 40 & 0.143082 \\
\hline $\begin{array}{l}\text { Chelate } \\
\text { Ebrahimabad }\end{array}$ & 20 & 0.390477 & Hasanabad & 41 & 0.116756 \\
\hline Mayan Vosta & 21 & 0.38897 & Sirzar & 42 & 0.116206 \\
\hline Sourc: Res & & & 32 \\
\hline
\end{tabular}

Source: Research findings, 2015.

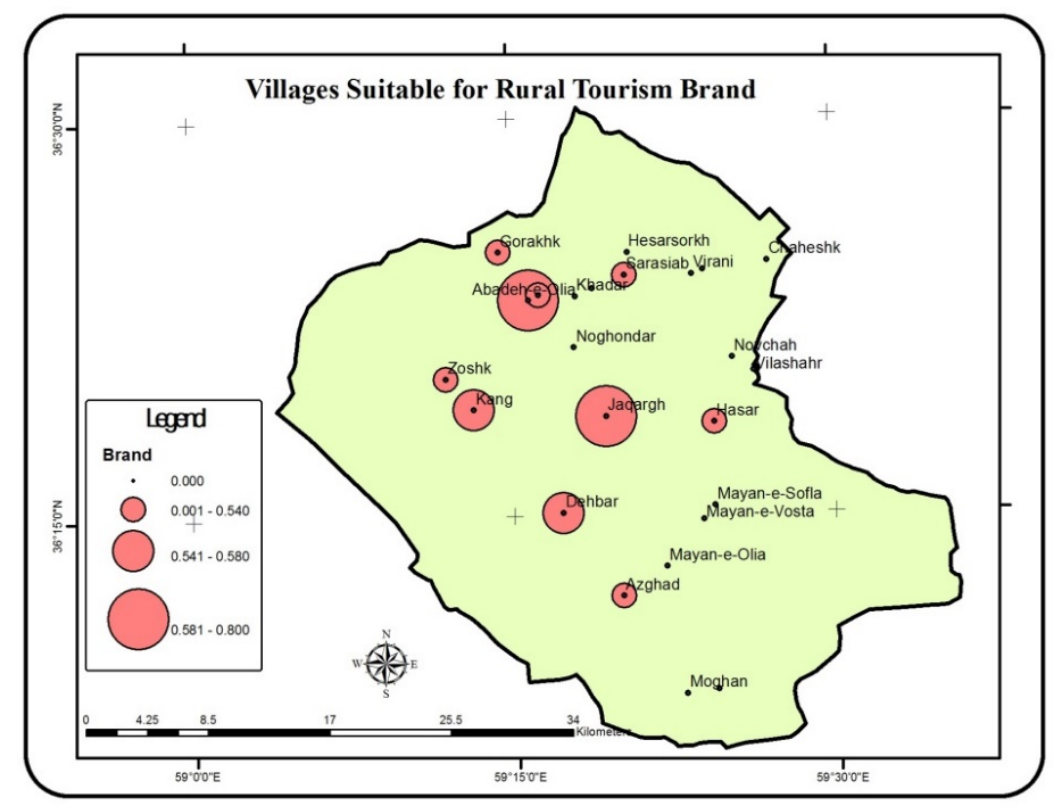

Figure-3 villages suitable for rural tourism brand

(Source: Research findings, 2015.) 


\section{CONCLUSION}

Today, branding of a tourism destination is one the most absorbing and controversial topics in the field of tourism marketing. The aim of this study was to identify the factors affecting the rural tourism brand in Iran. If branding is a strategic act and backed by logical thinking and based on target market needs, brand of a commodity or a destination should have functions in line with marketing. Each of these functions are output data of expected activities in marketing and branding. Based on exploratory studies, factors affecting rural tourism brand were in three categories: economic, social and physical-environmental ones among which, according to experts' views and utilizing Fuzzy Analytical Hierarchy Process (FAHP), economic factors with the impact coefficient of $54.6 \%$ had the maximum impact on recognition of a rural environment as a tourism brand. Among the 14 indexes affecting tourism brand, availability of particular products in a village with the impact coefficient of $14.2 \%$ and presence of entrepreneurs in rural environment with impact coefficient of $13.6 \%$ ranked first and second in affecting the recognition of a village as a tourism brand. As there was no similar study about the identifying the factors affecting the formation of a rural tourism brand, whether in Iran and other countries, it was not possible to compare its results with those of previous studies.

The results showed that Jagharq village, given to its attractions in economic, social and physicalenvironmental fields has had the minimum distance from the positive ideal in TOPSIS method, and was identified as the most suitable village for creation of rural tourism brand. The economic attractions of Jagharq included crops and fruits in the villages, entrepreneurs in the field of aquaculture, large investment in tourism industry, etc. The social attractions included cultural attractions such as old cemeteries, Shah Abbasi Caravansary, water mills, crafts, like carpet waving, Namad making, hand bags, Doll making, highly educated villagers, etc. The physical- environmental attractions of Jagharq included paved roads, facilities, utilities and basic infrastructure, tourism facilities such as restaurants, hotels, and large number of secondhomes.

Finally, to facilitate the process of creating rural tourism brand in the study area, the following guidelines could be helpful:

To give special attention to certain products of the region, such as crops and fruits (berries, cherries, walnut), dairying, coal, stone and wood works in the villages to create rural tourism brands.

To give special attention to entrepreneurship in rural areas to create new attractions in rural areas that could make way for development of tourism brand.

To provide tourism facilities such as restaurants, hotels in the villages of the study area, to attract more tourists and create a rural tourism brand.

To restore cultural elements and give more attention to the customs that are gradually dying out, which can create new opportunities to create a new rural tourism brand in the region.

\section{REFERENCES:}

Aaker, D. A. (1991). "Managing Brand Equity". The Free Press: New York, N.Y.

Amani, A. R., Pourchafi, P., Qane, R. \& Fakhraiee, A. (2011). "Planning the development of rural tourism with SWOT Model (Case study: Malhamdareh village of Sarvabad County)". Proceedings of the ${ }^{\text {st }}$ National Conference Geography \& Rural Planning \& Development, Ferdowsi University of Mashhad, Iran. (In Persian)

Arthur Rooney, J. (1995). "Branding: a trend for today and tomorrow". Journal of Product \& Brand Management, Vol.4, No.4, Pp.48-55.

Ataee, M. (2010). "Fuzzy multiple criteria decision". Shahroud: Industrial University of Shahroud Publication. (In Persian)

Ateljevic, J. (2007). "Small tourism firms and management practices in New Zealand: the Centre Stage Macro Region". Tourism Management, Vol.28, No.1, Pp.307-316.

Ayubi Yazdi, H. \& Bazrafshan, M. (2011). "The importance of brands and branding in tourist destinations". Proceedings of the $1^{\text {st }}$ National Conference Management \& Tourism Development, Challenges \& Solutions, Tehran, Sharif University of Technology Research Center, Retrieved Sept 16, 2015 from http://www.civilica.com/Paper-SHARIFURBAN01-SHARIFURBAN01_038.html. (In Persian) 
Ayubi Yazdi, H. \& Hosieni, S. M. H. (2011). "Brand status and challenges in tourism destinations". Proceedings of the $1^{\text {st }}$ International Conference on Intellectual Capital Management, Zanjan, Zanjan University Graduate School of Science, Retrieved Sept 16, 2015 from http://www.civilica.com/PaperIICM01-IICM01_037.html. (In Persian)

Baker, B. (2012). "Destination Branding for Small Cities". ( $2^{\text {nd }}$ ed.). Creative Leap Books. Portland. Oregon. USA.

Baker, M. J., \& Cameron, E. (2008). "Critical success factors in destination marketing". Tourism and hospitality research, Vol.8, No.2, Pp.79-97.

Baloglu, S., \& McCleary, K. W. (1999). "A model of destination image formation". Annals of tourism research, Vol.26, No.4, Pp.868-897.

Barezani, H. \& Zargham Borojeni, H. (2013). "Tourism brand pathology in Iran". Journal of New Marketing Research, Vol.3, No.8, Pp.63-80. (In Persian)

Blain, C. R. (2001). "Destination branding in destination marketing organizations" (Doctoral dissertation). University of Calgary.

Dastjerdi Yousefi, M. H. (2006). "Design strategic model of name and logo". Proceedings of the 1st International Conference on Management \& Marketing, Tehran, Ariana Research Group, Retrieved Sept 20, 2015 from http://www.civilica.com/Paper-IMMC01-IMMC01_062.html. (In Persian)

Dwyer, L., Edwards, D., Mistilis, N., Roman, C., \& Scott, N. (2009). "Destination and enterprise management for a tourism future". Tourism management, Vol.30, No.1, Pp.63-74.

Governor of Khorasan-e-Razavi. (2015). "The latest administrative divisions, Binalood County". Mashhad: Governor of Khorasan-e- Razavi. (In Persian)

Habibi, A., Izadyar, S. \& Sarfarazi, A. (2014). "Fuzzy multiple criteria decision". Rasht: Katibe-e-Gil Publication. (In Persian)

Hemati, R. \& Zahrani, D. (2014). "Factors affecting satisfaction and loyalty of foreign tourists to Isfahan as a tourism brand". Journal of Tourism Development \& Planning, Vol.3, No.10, Pp.182-204. (In Persian)

Hultman, J., \& Hall, C. M. (2012). "Tourism place-making: Governance of locality in Sweden". Annals of Tourism Research, Vol.39, No.2, Pp.547-570.

Jalalian, H., Namdari, F. \& Pashazadeh, A. (2014). "Effects of rural tourism on the development in Hajij village of Kermanshah". Journal of Applied Research of Geographic Sciences, Vol.15, No.36, Pp.205-228. (In Persian)

Johansson, J. (2008). "Working with events to build a destination brand identity-the DMO perspective". Rapport nr: Master Thesis 2007: 33.

Kaplanidou, K., \& Vogt, C. (2003). "Destination branding: Concept and measurement". Travel Michigan and Michigan State University, Department of Park, Recreation and Tourism Resources, 1-7.

Karami, S. \& Fakhraie, A. (2012). "Position and brand value in the development of tourism and attracting tourists". Proceedings of the $1^{\text {st }}$ National Conference on Geography and Tourism in the Third Millennium, Najafabad, Islamic Azad University of Najafabad Branch. Retrieved Sept 25, 2015 from http://www.civilica.com/Paper-NGTC01-NGTC01_048.html. (In Persian)

Kiani, Z. (2008). "Brand tourist destination and its role in the unity of the tourism industry stakeholders". Proceedings of the $1^{\text {st }}$ National Conference on Changes in the Environment for Tourism Development and Poverty Reduction, Tehran, Alame Tabatabaie University. (In Persian)

Mohammadi, S. (2011). "Rural development and tourism development". Journal of Sepehr, Vol.20, No.78, Pp.93-101. (In Persian)

Mollazadeh, A. \& Eftekharnia, M. (2011). "Evaluation of urban branding to attract tourists". Proceedings of the $1^{\text {st }}$ National Conference on Tourism Management \& Sustainable Development, Marvdasht, Islamic Azad University of Marvdasht Branch. Retrieved Sept 23, 2015 from http://www.civilica.com/Paper-TMSD01TMSD01_018.html. (In Persian)

Najafipour, A. A. Karoubi, M. \& Heydari, M. (2012). "Brand equity and position in tourism branding". Proceedings of the $1^{\text {st }}$ National Conference on Tourism and Ecotourism Iran, Hamedan, Islamic Azad University of Hamedan Branch, Retrieved Sept 26, 2015 from http://www.civilica.com/Paper-CTEI01CTEI01_199.html. (In Persian)

Novghani, M., ASgharpou-e-Masouleh, A. R., Safa, Sh. \& Kermani, M. (2008). "Citizen quality of life and its relationship to social capital". Journal of Social Sciences, Vol.5, No.1, Pp.111-140. (In Persian)

Popescu, R. I. (2009). "The branding potential of Bucharest". Strategy and success factors. Theoretical and empirical researches in urban management, Vol.4, No.4(13), Pp.177-193. 
Pourtaheri, M. (2010). "Application of Multiple Attribute Decision Making in Geography". Tehran: SAMT Publication. (In Persian)

Qalamkar Mo'azam, M. (2012). "The role of Iranian villages in tourism brand". Proceedings of the $1^{\text {st }}$ National Conference on Tourism and Ecotourism Iran, Hamedan, Islamic Azad University of Hamedan Branch, Retrieved Sept 22, 2015 from http://www.civilica.com/Paper-CTEI01-CTEI01_599.html. (In Persian)

Qu, H., Kim, L. H., \& Im, H. H. (2011). "A model of destination branding: Integrating the concepts of the branding and destination image". Tourism Management, Vol.32, No.3, Pp.465-476.

Ranjbaran, B., Khazaie Poul, J. \& Balouie-e-Jamkhaneh, H. (2012). "Analysis of the strengths, weaknesses, opportunities and threats foreign tourism Esfahan with FAHP technique". Journal of Tourism Development \& Planning, Vol.1, No.1, Pp.13-34. (In Persian)

Ritchie, J. \& Ritchie, R. (1998). "Destination marketing". International Association of Scientific Experts in Tourism Report, Vol.40, No.1, Pp.89-116.

Saeedi, A. (2000). "Principle of rural geography". Tehran: SAMT Press. (In Persian)

Sojasi. H., Romyani, A. \& Jafari, N. (2014). "Evaluation and assessment of rural tourism destinations from the views of local communities (Case study: Darb Gonbad Dehestan- Kohdasht County)". Journal of Spatial Planning (Geography), Vol.4, No.1, Pp.103-126. (In Persian)

Sorayyaee, A., Radmard, M., Radmard, M. \& Yonesi, A. (2012). 'The effect on the behavior of urban branding image of tourism in Ramsar County". Proceedings of the $1^{\text {st }}$ National Conference on Tourism and Ecotourism Iran, Hamedan, Islamic Azad University of Hamedan Branch, Retrieved Sept 26, 2015 from http://www.civilica.com/Paper-CTEI01-CTEI01_100.html. (In Persian)

Taghdisi, A., Varesi, H. R., Ahmadian, M. \& Asgari, H. (2015). "Identify and analysis the factors affecting development of tourism in rural areas (case study: Rural areas of Jiroft County)" .Journal of Research \& Rural Planning, Vol.4, No.9, Pp.1-14. (In Persian)

Vanolo, A. (2008). "The image of the creative city: Some reflections on urban branding in Turin". Cities, Vol.25, No.6, Pp.370-382.

Zahedi, Sh. (2006). "The Principle of sustainable tourism and ecotourism" $\left(1^{\text {st }}\right.$ ed.). Tehran: Alame Tabatabaie University Publication. (In Persian) 